Canadian Journal of Applied Linguistics

Revue canadienne de linguistique appliquée

\title{
Intercultural Communicative Competence and English for Academic Purposes: A Synthesis Review of the Scholarly Literature
}

\section{Scott Roy Douglas and Mark Rosvold}

Volume 21, Number 1, 2018

URI: https://id.erudit.org/iderudit/1050809ar

DOI: https://doi.org/10.7202/1050809ar

See table of contents

Publisher(s)

University of New Brunswick

ISSN

1920-1818 (digital)

Explore this journal

Cite this article

Douglas, S. \& Rosvold, M. (2018). Intercultural Communicative Competence and English for Academic Purposes: A Synthesis Review of the Scholarly Literature. Canadian Journal of Applied Linguistics / Revue canadienne de linguistique appliquée, 21(1), 23-42. https://doi.org/10.7202/1050809ar

\section{Article abstract}

With increasing numbers of students from culturally and linguistically diverse backgrounds enrolling in English for Academic Purposes (EAP) programs, understanding intercultural communicative competence can contribute to developing effective EAP pathways to higher education. This review of the literature was carried out to synthesize and uncover emerging themes related to intercultural communicative competence and EAP over a 20-year period from 1996 to 2016. A careful search found 15 scholarly works related to this topic. Papers were coded and analyzed for their key findings to reveal eight major themes: miscommunication, ethnocentrism, acculturation, awareness, ethnorelativism, identity, teaching and learning, and academic success. The scant literature related to the topic points to the need for further research. However, the findings do indicate how EAP practitioners can move away from ethnocentric perceptions and programs of study fixed on acculturation toward ethnorelative understandings and EAP classrooms that support intercultural awareness for both teachers and students.
Copyright (c) Scott Roy Douglas, Mark Rosvold, 2018

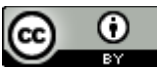

This document is protected by copyright law. Use of the services of Érudit (including reproduction) is subject to its terms and conditions, which can be viewed online.

https://apropos.erudit.org/en/users/policy-on-use 


\title{
Intercultural Communicative Competence and English for Academic Purposes: A Synthesis Review of the Scholarly Literature
}

\author{
Scott Roy Douglas \\ University of British Columbia \\ Mark Rosvold \\ University of British Columbia
}

\begin{abstract}
With increasing numbers of students from culturally and linguistically diverse backgrounds enrolling in English for Academic Purposes (EAP) programs, understanding intercultural communicative competence can contribute to developing effective EAP pathways to higher education. This review of the literature was carried out to synthesize and uncover emerging themes related to intercultural communicative competence and EAP over a 20 -year period from 1996 to 2016. A careful search found 15 scholarly works related to this topic. Papers were coded and analyzed for their key findings to reveal eight major themes: miscommunication, ethnocentrism, acculturation, awareness, ethnorelativism, identity, teaching and learning, and academic success. The scant literature related to the topic points to the need for further research. However, the findings do indicate how EAP practitioners can move away from ethnocentric perceptions and programs of study fixed on acculturation toward ethnorelative understandings and EAP classrooms that support intercultural awareness for both teachers and students.
\end{abstract}

\section{Résumé}

Il y a un nombre croissant d'étudiants d'origines culturelles et linguistiques diverses dans les programmes d'anglais à des fins académiques (PAFA). Par conséquent, la compréhension des compétences en communication interculturelle peut contribuer à développer les voies d'accès efficaces au PAFA vers les études post-secondaires. Cette recension des écrits a été réalisée pour synthétiser et découvrir les thèmes émergents liés à la compétence en communication interculturelle et au PAFA pendant une période de 20 ans, de 1996 à 2016. Notre recherche a trouvé 15 articles liés à ce sujet. Les articles ont été codés et analysés pour leurs résultats clés afin de révéler huit thèmes principaux : mauvaise communication, ethnocentrisme, acculturation, sensibilisation, ethnorelativisme, identité, enseignement et apprentissage, et réussite scolaire. Les écrits scientifiques limités liés au sujet font ressortir le besoin de recherches supplémentaires. Cependant, les résultats ont indiqué les façons dont les praticiens du PAFA pouvaient s'éloigner des perceptions ethnocentriques et des programmes d'études axés sur l'acculturation vers des compréhensions ethnorelatives et des salles de classe du PAFA qui favorisent la sensibilisation interculturelle des enseignants et des élèves. 


\section{Intercultural Communicative Competence and English for Academic Purposes: A Synthesis Review of the Scholarly Literature}

\section{Introduction}

In countries such as Canada, Australia, New Zealand, the United States, and the United Kingdom, there have been growing numbers of international students from linguistically diverse backgrounds seeking entry to higher education. In Canada, for example, the federal government has plans to double the overall population of international students to 450,000 by 2022 (Foreign Affairs, Trade and Development Canada, 2014). Added to rising numbers of international students, in the Canadian context, there are also growing numbers of domestic students from linguistically diverse backgrounds heading toward higher education. From 2003 to 2012, approximately 2.5 million newcomers arrived in Canada (Citizenship and Immigration Canada, 2013), contributing to diverse multilingual cities such as Vancouver, where $31 \%$ of the population speak a language other than English or French at home (Statistics Canada, 2012). For many young newcomers, there are strong aspirations for higher education (Grayson, 2008; Krahn \& Taylor, 2005).

With an increasing focus on internationalization in higher education (e.g., University of British Columbia, 2011), growing numbers of university-bound international and domestic students from diverse linguistic backgrounds, and a rising demand for English for academic purposes (EAP) pathways for those students, a systematic review of the scholarly literature on how intercultural communicative competence manifests within EAP settings is timely and relevant. In particular, such a review can serve as an initial inquiry pathway for both novice and seasoned EAP practitioners who are beginning to explore this topic. The current critical review examines the scholarly literature related to intercultural communicative competence within postsecondary EAP settings. It is an attempt to understand the relationship between intercultural communicative competence and EAP, with the aim of uncovering the key themes in the literature most useful to EAP practitioners and their continuing professional development needs. While there has been a wide range of studies examining intercultural communicative competence and additional language learning in general, a specific focus on EAP settings can serve to disaggregate these findings from numerous other studies without an EAP focus, in order to highlight unique considerations related to the culture of higher education. Thus, the guiding inquiry question for this systematic review and synthesis of the scholarly literature related to intercultural communicative competence and EAP is as follows:

How do understandings of intercultural communicative competence manifest within EAP settings in higher education?

\section{Literature Review}

\section{English for Academic Purposes (EAP)}

Programs of EAP can offer students from linguistically diverse backgrounds an alternative pathway to English-medium higher education, with students who successfully complete an EAP program typically being exempt from having to submit standardized English language proficiency test scores, such as the TOEFL or IELTS tests, before 
beginning their subject specific programs of study. Often, these programs are designed for academically qualified students from language backgrounds other than English who score below mandated English language proficiency requirements for entry into English-medium higher education. Programs typically consist of courses aiming to develop the academic English language proficiency that facilitates postsecondary studies in English, with the goal of helping learners to study and conduct research in English (Flowerdew \& Peacock, 2001). Rather than having the English language as the general subject of study, EAP can be focused on acquiring the language and communication skills needed to access subject content related to students' future or current studies (Kennedy, 2001). These programs can be contrasted with other English language courses because students have the goal of entering higher education and gaining a degree qualification. These programs involve more than just learning about language, they are also about learning how to successfully take part in the postsecondary experience in a different language and culture (Jund, 2010). Thus, EAP can focus on the particular cognitive, linguistic, social, and academic demands of postsecondary contexts, with special attention paid to students' various academic disciplines. Typically, EAP does not just prepare students for study in English, it aims to foster the specialized literacy and communicative skills encountered in higher education (Hyland, 2006; Hyland \& Hamp-Lyons, 2002).

\section{Culture}

Culture and EAP are intertwined, but culture can be a difficult concept to define. Sauvé (1996) has pointed out that there are a number of variables that impact a definition of culture, including location, age, ethnicity, gender, and class, to name a few. Furthermore, some aspects of culture, such as values and beliefs, may not be easily observed compared to other aspects, such as language and behaviour (Hall, 1976). For Bennett (1998), the observable characteristics of culture, termed objective culture, are related to cultural products and institutions such as food, holidays, stories, and clothing. However, the unobservable aspects, referred to as subjective culture, are related to behaviour, values, and ways of thinking. It further seems that cultures themselves are rarely homogeneous, with aspects evolving and changing in unexpected ways (Atkinson, 1999). Because of this, Atkinson (1999) proposed a view of culture related to English language teaching that moves away from essentialized and received notions of culture in which cultural norms are uncritically perceived as static, consistent, and unproblematic, toward what Spack (1997) conceived as a more fluid and non-deterministic view of culture. Consequently, Atkinson proposed a concept of culture in relation to English language teaching that takes into account people's individuality and agency within varied social contexts and social groups without reducing them to stereotypes. However, social contexts and groups do have cultural impact on individuals, with language and culture being interrelated in multiple, complex, and consequential ways. Taking care to avoid cultural essentialism and reductionist generalizations and taking into account individual agency and independence as recommended by Atkinson, culture can be understood as a shared set of norms, values, and beliefs that influence people's interactions and behaviours (Deardorff, 2010). It consists of symbolic resources such as fashion, knowledge, images, ideologies, and language, and the ways in which people, both collectively and individually, interpret and understand these resources (Singh \& Doherty, 2004). 


\section{Intercultural Competence}

Bickley, Rossiter, and Abbott (2014) have identified six areas in which there may be different value orientations across cultural groups: time conceptions, power relations, communication styles, task focus, concepts of universality, and feelings of individuality. Bennett $(1993,1998)$ has pointed out that when individuals encounter different languages, behavioural norms, and values, there is the possibility that these differences may result in negative feelings and miscommunication. In particular, these negative feelings might arise during an intercultural interaction because of a perception that a situation is difficult to control or that it may be unlikely that the interaction will result in a fair outcome for both parties. For Bennett, the concept of intercultural competence is related to the ability to cope successfully with these types of cultural differences. This ability to cope ranges across six stages in Bennett's (1993) developmental model of intercultural sensitivity (DMIS): from ethnocentric perceptions of difference that involve denying difference, defending against difference, and minimizing difference to ethnorelative perceptions of difference that involve accepting difference, adapting to difference, and integrating difference.

Complementing the DMIS, Deardorff (2006) has seen intercultural competence as a process that begins with an attitude of respect, openness, and curiosity. It also involves selfawareness and the skills to listen, observe, evaluate, analyze, and relate to others. These skills can result in internal outcomes connected to becoming more adaptable, flexible, and empathetic within an ethnorelative mindset, and external outcomes connected to behaving and communicating effectively and appropriately in intercultural situations. Intercultural competence can be known by other terms, depending on the field of study. Deardorff (2011) noted that it is sometimes referred to as multicultural competence, cross-cultural awareness, cultural intelligence, or global citizenship, with all of these related to interactions with people from different cultural backgrounds.

\section{Communicative Competence}

Communicative competence can play an important role in overall intercultural competence. The idea of communicative competence was first conceived by Hymes (1966) in order to account for the fact that the rules that influenced the ability to use language effectively seemed to go beyond a simple knowledge of grammar. In addition to grammar, communicative competence includes knowledge about "when to speak, when not, and as to what to talk about with whom, when, where, in what manner" (Hymes, 1972, p. 277). Canale and Swain (1980) developed their conception of communicative competence to include three communicative aspects: grammatical competence, sociolinguistic competence, and strategic competence. Grammatical competence includes knowledge of vocabulary, grammar, syntax, semantics, and phonology. It is important for understanding and producing literal meanings. Sociolinguistic competence involves sociocultural aspects of language use and understanding social meanings, particularly when the literal meaning is dissimilar to a speaker's intended meaning. It is related to the appropriate use of language. The final aspect in Canale and Swain's understanding of communicative competence is strategic competence. Strategic competence is the ability to deploy strategies, both verbal and nonverbal, to repair communication when it breaks down either in relation to grammatical competence or sociolinguistic competence. Since Canale and Swain's conception of communicative competence, the model has been expanded to include further 
dimensions such as discourse competence at the suprasentential level of language (Canale, 1983) and actional competence, in order to include knowledge of how to engage in speech acts (Celce-Murcia, Dörnyei, \& Thurrell, 1995). Further to these developments, CelceMurcia (2007) has proposed a comprehensive model of communicative competence that consists of six interlocking components that interact with each other: discourse competence (knowledge of how words are put together); sociocultural competence (knowledge of how messages are appropriately conveyed); linguistic competence (knowledge of phonology, vocabulary, morphology, and syntax); formulaic competence (knowledge of fixed and prefabricated chunks of language); interactional competence (knowledge of how to carry out speech acts and engage in conversation); and strategic competence (knowledge of how to learn and maintain language use). The six components of Celce-Murcia's model of communicative competence are dynamic and can provide a holistic base for developing additional language courses, such as an EAP course for postsecondary bound students from linguistically diverse backgrounds.

\section{Intercultural Communicative Competence}

Considered together, intercultural competence and communicative competence can be conceived as intercultural communicative competence. When individuals are using English as an additional language, interactions in English are necessarily intercultural when speakers are from diverse cultural backgrounds. The intercultural nature of these communicative interactions should be taken into account (Krasnick, 1985), with intercultural communication skills being an essential aspect of overall communicative competence. As seen in the previous section, communicative competence includes more than just linguistic competence. It also includes an intercultural competence that respects interlocutors' identities, values, and traditions (Garcia-Perez, Ragoonaden, \& Campbell, 2014). Byram (1997) underlined the importance of the relationship between intercultural competence and linguistic competence. When intercultural interactions take place successfully in an additional language, such as in an EAP classroom, it underscores the importance of linguistic competence as an aspect of intercultural competence; Byram referred to this as intercultural communicative competence. Speaking in the language of another person, building a relationship with that person, and communicating effectively even when the other person may have different ways of thinking fosters intercultural communicative competence. Byram maintained that when additional language users possess intercultural communicative competence, they are better able to communicate with others because of their understanding of their own cultural perspectives as well as those of the people with whom they are communicating. In short, intercultural communicative competence "is the ability [in an additional language] to communicate effectively and appropriately with people from other language and cultural backgrounds" (Sun, 2014, para. 24). This ability involves empathy, respect, tolerance, sensitivity, flexibility, and openness to interacting with people from other cultures and linguistic backgrounds in ways that do not impose dominant or so-called "native speaker norms" (Sun, 2014). Understanding an interlocutor's social and cultural frame of reference is essential for effective and meaningful communication. Taking these understandings into account, intercultural communicative competence can be defined as communication in an additional language between people from varying cultural backgrounds that suites a particular context while achieving an anticipated goal. The desired outcomes are achieved through the interlocutors 
having an understanding of their own cultural perspectives while valuing the perspectives of others. However, within this definition, it is important not to assume culture to be a tightly bound and closed system, with the communication taking place across fixed lines. Rather, more fluid conceptions of culture in which non-homogeneity is recognized along with individual agency, hybridity, and shifting identities complement the above definition.

\section{Reviewing the Literature on Intercultural Communicative Competence and English for Academic Purposes (EAP)}

Focusing on the scholarly literature related to intercultural communicative competence and EAP over a 20-year period from 1996 to 2016, review data were collected in two ways. First, major journals in the Canadian context were examined for each year during the time period under consideration for articles related to both intercultural communicative competence and EAP. These journals included the TESL Canada Journal, the Canadian Journal of Applied Linguistics, and the Canadian Modern Language Review. Next, the Educational Resources Information Center (ERIC) database and the ProQuest Dissertations and Theses Global Database were searched for keywords related to intercultural communicative competence and EAP, such as intercultural communicative competence, intercultural competence, cross-cultural awareness, English for academic purposes, intensive English language programs, and variations thereof. The research team consisted of myself, the lead author of this paper, and a graduate research assistant. We each carried out a search of the literature independently, and then we compared our results to create one list of possible scholarly works for inclusion in the review. The search was also supported by the subject librarian at our home academic institution. Only scholarly works published in the 20 -year time period under investigation that included reference to both intercultural communicative competence and EAP (or close variations of those concepts) were included in the critical review. The detailed search resulted in finding 15 scholarly works connected to both intercultural communication and EAP.

Of the 15 scholarly works selected for inclusion, 13 were peer reviewed articles and two were MA theses. Although careful attention was paid to only include works that referred to concepts related to both intercultural communicative competence and EAP, the majority of the scholarly works found did not have intercultural communicative competence as the main focus of investigation. Rather, intercultural communicative competence might be an outcome of the investigation (Clennel, 1999; Spiliotopoulos \& Carey, 2005); an implication based on scholarly inquiry (Basturkmen, 2000; Cheng \& Fox, 2008; Ellwood \& Nakane, 2009; Singh \& Doherty, 2004; Thatcher, 2004); or a part of an EAP course curriculum (Campbell, MacPherson, \& Sawkins, 2014; Liu, 2007; Stoller, 1999). There were just four peer reviewed articles (Galante, 2014; Garcia-Perez et al., 2014; Jund, 2010; Ruhe, 1998) and one MA thesis (Martin, 2016) in which concepts related to intercultural communicative competence and EAP were the main focus of the scholarly inquiry. Table 1 summarizes the scholarly works included in the review of the literature. 
Table 1

Summary Table of Literature Related to Intercultural Communicative Competence and English for Academic Purposes (EAP)

\begin{tabular}{|c|c|c|c|}
\hline Author(s) & Context & Participants & Methodology \\
\hline Basturkmen (2000) & $\begin{array}{l}\text { EAP/Proficient } \\
\text { Speakers (UK) }\end{array}$ & $\begin{array}{l}30,000 \text {-word corpus } \\
\text { (18 tutorial } \\
\text { discussions) }\end{array}$ & Discourse analysis \\
\hline $\begin{array}{l}\text { Campbell, } \\
\text { MacPherson, \& } \\
\text { Sawkins (2014) }\end{array}$ & EAP (Canada) & $\begin{array}{l}18 \text { students; } 20 \\
\text { teachers }\end{array}$ & Program description \\
\hline Cheng \& Fox (2008) & $\begin{array}{l}\text { Undergraduate, EAP, } \\
\text { ESL (Canada) }\end{array}$ & 56 students & Grounded theory \\
\hline Clennell (1999) & EAP (Australia) & 15 students & Qualitative \\
\hline $\begin{array}{l}\text { Ellwood \& Nakane } \\
\text { (2009) }\end{array}$ & EAP (Australia) & $\begin{array}{l}35 \text { students (total); } 4 \\
\text { teachers }\end{array}$ & $\begin{array}{l}\text { Classroom } \\
\text { ethnography }\end{array}$ \\
\hline $\begin{array}{l}\text { Galante (2014) } \\
\text { Garcia-Perez, } \\
\text { Ragoonaden, \& } \\
\text { Campbell (2014) }\end{array}$ & $\begin{array}{l}\text { EAP (Canada) } \\
\text { EAP (Canada) }\end{array}$ & $\begin{array}{l}n \text { not reported } \\
8 \text { students }\end{array}$ & $\begin{array}{l}\text { Project description } \\
\text { Mixed methods }\end{array}$ \\
\hline Jund (2010) & EAP (USA) & $\begin{array}{l}n \text { not reported (12 } \\
\text { groups) }\end{array}$ & $\begin{array}{l}\text { Discursive } \\
\text { psychology }\end{array}$ \\
\hline Liu (2007) & EAP (Canada) & 5 students & Qualitative \\
\hline Martin (2016) & EAP (Canada) & 50 students & Mixed methods \\
\hline Ruhe (1998) & $\begin{array}{l}\text { EAP/Composition } \\
\text { (Canada/USA) }\end{array}$ & $\begin{array}{l}\sim 82 \text { (exact } n \text { not } \\
\text { reported) }\end{array}$ & Project description \\
\hline $\begin{array}{l}\text { Singh \& Doherty } \\
(2004)\end{array}$ & EAP (Australia) & 9 teachers & Qualitative case study \\
\hline $\begin{array}{l}\text { Spiliotopoulos \& } \\
\text { Carey (2005) }\end{array}$ & $\begin{array}{l}\text { EAP Writing } \\
\text { (Canada) }\end{array}$ & 18 students & $\begin{array}{l}\text { Ethnography / } \\
\text { grounded theory }\end{array}$ \\
\hline Stoller (1999) & EAP (USA) & $n$ not reported & Program description \\
\hline Thatcher (2004) & $\begin{array}{l}\text { EAP researchers, } \\
\text { writers, teachers } \\
\text { (UK) }\end{array}$ & $n$ not reported & Contrastive rhetoric \\
\hline
\end{tabular}

Note. $\mathrm{ESL}=$ English as a second language.

Once the scholarly works for the critical review were identified, the analysis was guided by a qualitative approach (Gay, Mills, \& Airasian, 2012) in which we attempted to 
bracket our preconceptions of what we might find (Creswell, 1998). We examined each paper and assigned descriptive codes to passages with phrases and sentences that could stand on their own as a unit of meaning related to intercultural communicative competence and EAP. We developed the descriptive codes as we encountered key ideas in the scholarly works being analyzed. Examples of codes used are included in Table 2. During the coding process, validity and reliability in the analysis were promoted by comparing our codes with each other before gathering them together. Codes were then collected into the most salient emerging themes. The process of coding and gathering the codes into themes was iterative in nature in order to create as clear a picture as possible of the prevailing themes found in the literature in relation to intercultural communicative competence and EAP. These themes are presented as the synthesized findings of the critical literature review. The major themes are miscommunication, ethnocentrism, acculturation, awareness, ethnorelativism, identity, teaching and learning, and academic success.

Table 2

Examples of Emerging Themes and Associated Codes

\begin{tabular}{|c|c|}
\hline Theme & Examples of Associated Codes \\
\hline \multirow{3}{*}{ Miscommunication } & Miscommunication \\
\hline & Misconceptions \\
\hline & Appropriateness \\
\hline \multirow[t]{3}{*}{ Ethnocentrism } & Ethnocentrism \\
\hline & Difference \\
\hline & Second Language Adaptation \\
\hline \multirow[t]{4}{*}{ Acculturation } & Power \\
\hline & Cultural Expectations \\
\hline & Target Culture \\
\hline & Cultural Adaptation \\
\hline \multirow[t]{3}{*}{ Awareness } & Self-Awareness \\
\hline & Intercultural Awareness \\
\hline & Empathy \\
\hline \multirow[t]{4}{*}{ Ethnorelativism } & Ethnorelativism \\
\hline & Characteristics \\
\hline & Skills \\
\hline & Bi-Directionality \\
\hline \multirow[t]{3}{*}{ Identity } & Challenge \\
\hline & Identity \\
\hline & Intersectionality \\
\hline \multirow[t]{4}{*}{ Teaching and Learning } & Pedagogy \\
\hline & Teacher Awareness \\
\hline & Time \\
\hline & Language \\
\hline Academic Success & Academic Success \\
\hline
\end{tabular}




\section{Findings}

\section{Miscommunication}

A key theme to emerge in the review of the literature of intercultural communicative competence and EAP was that of miscommunication related to misconceptions and appropriate choice of communication strategies during intercultural encounters. Investigating oral interactions between EAP students and their peers from English-speaking backgrounds in Australia, Clennell (1999) found that misunderstanding a speaker's pragmatic meaning could be one cause of intercultural miscommunication. For example, in Clennell's study, a participant understood what was being said to her, but she mistakenly thought her behaviour was being criticized. In other situations, in the same study, students were misinterpreting whether or not someone was being rude to them. Clennell concluded that EAP students needed strategies for dealing with these types of intercultural communication breakdowns. Basturkmen (2000) also found that EAP students in the UK could appear impolite or critical because of difficulties using indirect language. For Galante (2014), misunderstandings and trouble communicating with local people and students from other countries could be confusing for additional language learners because they may not understand why the miscommunication is taking place. These types of communication breakdowns can have negative consequences for intercultural EAP classrooms. For example, Ellwood and Nakane (2009) identified that teaching and learning experiences could suffer when culturally bound expectations related to speaking and silence in class were not effectively communicated.

\section{Ethnocentrism}

Ideas related to ethnocentrism, particularly in connection to cultural differences and adapting to dominant cultural norms, were also found during the literature review of intercultural communicative competence and EAP. In the literature, it appeared that some teachers practicing in EAP settings may have reinforced the idea of cultural difference and international student responsibility for adapting to their new cultural surroundings, with detrimental effects on intercultural communication. Singh and Doherty (2004) found that while EAP teachers in their study may have desired to respect the cultures students brought with them, the EAP teachers also tended to reinforce notions of polarized cultural differences, such as the dominant learning styles of different cultural groups, without taking into account the complexities of globalization and individual variation. The danger recognized by Jund (2010) is that these types of approaches that focus on contrasting cultures can result in stereotypes, oversimplification, and essentialist understandings of cultural differences.

Essentialist understandings of cultural differences were also identified by Ellwood and Nakane (2009). In their investigation of the privileging of speech in EAP classrooms, local teachers at an Australian university appeared to engage in essentialist cultural stereotyping of Japanese students. It appeared that the teachers in the study had the impression that the Japanese educational system was a poorer system because of a perceived authoritarian and hierarchical nature that resulted in students who were silent, and who were unable to critically engage with curricular content, question authority, or 
speak in a relaxed manner with teachers. Teachers in the study maintained that European students were better critical thinkers than Japanese students, the facial expressions of Japanese students were difficult to read, and silence on the part of Japanese students was a cultural trait. One teacher even went so far as to claim that Japanese students had a "sort of alien quality and inscrutability" (Ellwood \& Nakane, 2009, p. 214). Based on these findings, Ellwood and Nakane referred to the EAP teachers in their study as "assimilationist" (p. 226). Based on essentialist notions of Japanese culture in the Ellwood and Nakane's study, teachers may not have understood why their Japanese students were being silent, or how their classroom practices could be reinforcing that silence. Furthermore, because of their reductionist and negative impressions of the perceived cultural traits of their students, the fact that the silence might have been a positive development often did not occur to the teachers. Intercultural competence, such as conceived of by Bennett (1993) and Deardorff (2006), was rather a narrow one-way flow of EAP students needing to adapt to local norms. In the Ellwood and Nakane study, responsibility was placed on the Japanese students to participate and not remain silent. At the same time, the teachers did not feel required to examine their own relationship with silence. It may have been the case that classroom practices were inhibiting the Japanese students, even if they wanted to become more articulate and expressive in class. In order to ameliorate classroom interactions, teachers would need to move away from ethnocentric points of view and reconsider how they conceived silence and discussion in culturally diverse classrooms (Ellwood \& Nakane, 2009).

As a way of encouraging student adaptation (but not necessarily accommodation on the part of the host culture), integrated intercultural communication courses in EAP programs of study that focus on cultural adaptation to local norms have been developed with the stated goal of improving speaking and listening skills while also improving intercultural competence (Stoller, 1999). This understanding of intercultural competence in which EAP students seek to gain the skills to integrate into the local academic culture can also be seen in calls for students from language backgrounds other than English to learn how to take part in discussions using dominant cultural modes (Basturkmen, 2000). Along these lines, there did not seem to be a call for local students from the dominant culture to become sensitized to newcomer modes of discourse. In the literature, there is a sense that "students [from linguistically diverse backgrounds] have to change behaviors common to their native culture and accommodate those of the target culture" (Cheng \& Fox, 2008, p. 319). Similarly, in EAP writing contexts, Thatcher (2004) has recognized that ethnocentrism results when a mutual understanding of contrastive textual organizations is not understood, and dominant forms and purposes for writing are seen as the norm across cultures.

\section{Acculturation}

Acculturation, in the form of adapting EAP students from diverse cultural backgrounds to local cultural and academic norms, was also a theme found in the literature reviewed. One project designed to develop international students' intercultural communicative competence had students from culturally and linguistically diverse backgrounds interview local students at an Australian university (Clennell, 1999). As a cultural awareness raising exercise, international students in this project collaborated with their peers and their teacher to decide what it would be appropriate to say and what the 
cultural expectations would be during an interview with a student from an English-speaking background. To do this, they considered questions such as "How do you imagine an average Australian might feel when asked for an interview in this way? What strategies would be appropriate in your culture for accepting or declining such a request?" (Clennell, 1999, p. 87). After the interviews, the international students analyzed the answers to their interview questions for issues with intercultural communicative competence such as how to address people, how to be polite, and how long to pause without speaking. Students were then responsible for exploring their own problems communicating with others. For Clennell (1999), this gave international students the chance to understand the differences between Anglo-Australian culture and their own Asian cultural origins. Further exploration was done to analyze differences between students from different Asian cultural backgrounds. Likewise, Stoller (1999) had students from linguistically diverse backgrounds interact with proficient English language users in an EAP program as a means of learning how to interact with them.

Ruhe (1998) also felt that these types of interchanges between EAP and non-EAP students could offer cultural insights. However, the cultural adaptation process described above can be a difficult task for teachers due to the sometimes conflicting demands of an EAP curriculum designed to acculturate students and the teachers' professional ethics of cultural respect (Singh \& Doherty, 2004). For Ruhe, the typical emphasis on mainstream or immigrant cultures in Canadian classrooms should be contextualized within broader global cultural understandings. Programs of EAP should avoid offering idealized versions of an academic host culture that likely does not reflect current realities and hides the complexities of modern English-medium academic institutions (Singh \& Doherty, 2004).

\section{Awareness}

Intercultural awareness was another common theme in the literature reviewed. Based on their finding that undergraduate students from language backgrounds other than English may think that their intercultural competence skills are greater than they actually are in practice, Garcia-Perez et al. (2014) concluded there was an initial lack of intercultural awareness on the part of the students. As a result, it was put forward that classrooms can be a place for students to gain a greater self-awareness of their own culture while also gaining a greater awareness of other cultures. English for academic purposes classrooms can become a place for students to examine their own "unstated, culturally determined values" (Stoller, 1999, p. 11) and through working with other students from culturally diverse backgrounds, EAP students can become "more aware of their own cultural identity" (Spiliotopoulos \& Carey, 2005, p. 98).

Students studying EAP having greater self-knowledge of themselves as cultural beings appears to be a strong foundation for improved intercultural awareness. For example, Galante (2014) found that when students were critically self-aware, they were better able to think about relationships between people from different cultures within and without classroom settings. Through an exploration of the experiences of others, students were better able to increase their own appreciation of intercultural relationships. Also in a postsecondary setting, Spiliotopoulous and Carey (2005) found that electronic bulletin boards used in an academic writing class could foster intercultural awareness. In particular, as students were finding a sense of community and creating a collective identity as a class using online bulletin boards, they were also learning more about their peers from other 
cultural backgrounds and gaining an awareness of their cultural differences. Similar to electronic bulletin boards, Ruhe (1998) found that using email exchanges as an anxietylowering pedagogical tool led to increased intercultural awareness and an understanding of shared cultural traits within a global context.

In addition to projects designed to foster greater intercultural awareness as an outcome of an EAP experience, endeavours such as Campbell et al.'s (2014) pilot curriculum project explicitly set out to teach intercultural skills and raise intercultural awareness based on authentic and practical real-life activities. Similarly, in the program description presented by Stoller (1999), intercultural understanding was a pedagogical goal. In Stoller's program there was a separate course on intercultural communication that was part of the overall EAP course of studies, and in this course, students worked on gaining greater intercultural sensitivity and understanding of other cultural systems. In another EAP program (Martin, 2016), students could become more aware of the subjectivity of culture and how it affects behaviour, thinking, and values. Through this awareness, EAP students were better able to explain their experiences relating to cultural differences and how they perceived intercultural interactions.

\section{Ethnorelativism}

Ethnorelativism was another important theme in the literature related to intercultural communicative competence and EAP. Ethnorelativism refers to increasing cultural acceptance, adaptation, and integration in which an individual is at ease with other cultural perspectives and is able to interact appropriately and effectively in intercultural situations (Bennett, 1993; Deardorff, 2006). Although ethnocentric practices in EAP settings were clear in the literature, there was also evidence of how EAP classrooms can foster a change away from ethnocentrism towards ethnorelativism, in which there is more acceptance, adaptation, and integration of difference (Bennett, 1993). The role of the teacher is central to moving away from ethnocentric perspectives. Jund (2010) has pointed out that teachers can help students understand narrow cultural representations that may come up in the classroom and move the class toward intercultural understanding.

Similarly, Thatcher (2004) maintained that EAP scholars could avoid ethnocentrism if they took on an intercultural point of view and had a greater understanding of literacy in an additional language. Students can further rid themselves of stereotypical ideas connected to different cultures and begin to empathize with each other when they start to appreciate their own misunderstandings about other cultures through opportunities to communicate with students from other cultures (Spiliotopoulos \& Carey, 2005). Galante (2014) saw her students transitioning from ethnocentric perspectives to ethnorelative understandings during a digital literacy project in which "denial, defence, and minimization" (p. 56) made way for "acceptance, adaptation, and integration of cultures" (p. 56). In Galante's project, students saw that other cultures may have unique world views, and they began to recognize cultural differences. Similarities and differences between cultures were seen as depending on an individual's point of view, and students realized that accepting other students' cultural differences was an important part of cultural acceptance. For this cultural acceptance to come about, it was important for EAP teachers to foster an understanding of the host culture of a new place, which involved appreciating newcomer students' own experiences and cultural perspectives. For Galante, the multicultural EAP classroom was an ideal location for projects and intercultural interactions to raise students' intercultural sensitivity 
and provide students with an opportunity to empathize with other students from diverse cultural backgrounds.

\section{Identity}

The role of identity and the complexity of moving toward ethnorelative understandings was also evident during the literature review. Cheng and Fox (2008) noted the challenge of intercultural interaction in their study, and how this form of contact involved students attempting to preserve their own culture while also learning about the host culture. For the participants in the Cheng and Fox study, living in an English-language environment and interacting with people from English-speaking backgrounds could be difficult. To help students navigate this balancing act between preserving identity and understanding another culture, teachers could take on the complex task of integrating intercultural competence in such a way that affirms students' cultural identities while fostering a respect for cultural diversity (Galante, 2014). Irrespective of language abilities or cultural knowledge, Martin (2016) has posited that EAP students are intercultural social agents who have to negotiate between their own cultural backgrounds and those of the people with whom they are communicating. Students' identities are not static concepts (Jund, 2010). There are times when students may not accept perceptions of cultural differences being imposed on them by others, and there are other times when they may agree with those differences. Furthermore, Jund (2010) identified that cultural understandings are complex, with many aspects that are influenced by a number of factors such as age, location, and politics. Moreover, both teachers and students have agency and the opportunity to be influenced by intercultural encounters (Singh \& Doherty, 2004). As a result, cultural understandings are typically neither simple nor generalizable. Ellwood and Nakane (2009) reinforced Jund's understandings by questioning explicit links between student behaviours and culture. They concluded that teachers may make mistaken assumptions based on cultural explanations, and that students may do this too. This misconceived connection between culture and behaviour can lead to erroneous cultural justifications for behaviour, whereas the situation is likely more complex with other issues being involved such as course topics, sexuality, student relationships, and gender identity (Ellwood \& Nakane, 2009).

\section{Teaching and Learning}

As part of the teaching and learning experience, intercultural communicative competence as a learning objective was another theme in the surveyed literature. In particular, language classes were identified as a place for increasing intercultural competence and cultural awareness (Garcia-Perez et al., 2014). The teaching of cultural issues was seen as an important aspect of the additional language classroom, with the overall goal of developing intercultural communicative competence in students (Liu, 2007). Interculturality was put forward as an important aspect of communicative competence, and integral to language teaching (Galante, 2014). Learning objectives associated with an EAP course included exploring and expanding cultural understandings related to behaviours, values, and beliefs; increasing intercultural sensitivity; and providing useful intercultural skills for social, academic, and work contexts (Galante, 2014). Likewise, teachers in a pilot pathways project were looking at providing students with behavioural, emotional, and 
thinking skills that facilitate intercultural interactions in a wide range of contexts (Campbell et al., 2014). Achieving these learning objectives appeared to be related to the amount of time students were able to spend in an EAP setting. Martin (2016) found that time in EAP classrooms was related to intercultural communicative competence, with aspects of intercultural communicative competence further developing with more time spent in an EAP program.

How to reach the above learning objectives associated with intercultural communicative competence in EAP settings was also addressed in the literature with depictions of learning activities. Galante (2014) had students complete a digital literacy project to create videos in order to foster their understanding of intercultural relationships. To create the videos, students proposed their own topics connected to negative intercultural experiences such as being seen as rude, encountering different values and beliefs, or being unable to relate to another person. The students discussed, scripted, recorded, edited, and reflected on the video-making experience. Investigating these intercultural aspects of additional language learning was seen as a particularly valuable teaching activity in multicultural contexts such as the site for Galante's project. Students were able to increase their intercultural sensitivity by grounding that sensitivity in their own critical experiences. Galante concluded that integrating intercultural competence with additional language learning in a postsecondary context promoted an understanding of and respect for cultural diversity.

Activities can become an alternative tool used by EAP students in order to develop a collective identity along with increased intercultural interactions and awareness (Spiliotopoulous \& Carey, 2005). These activities can go further than simply comparing and contrasting cultural differences (Jund, 2010). Additionally, EAP instructors can develop their communication practices to become more effective teachers by taking into account the needs of the students (Ellwood \& Nakane, 2009). Along these lines, Jund (2010) felt it was important to create "spaces for international students to achieve crosscultural understanding and to develop intercultural relationships" (p. 2). Jund explored these spaces by investigating students' classroom talk during small group interactions on the topic of traditional clothing in a content-based course. In this course, students watched videos, read articles, and wrote about topics related to fashion and attire. The students dipped into their own culturally, ethnically, and linguistically diverse backgrounds during a wide range of discussion activities as they shared stories and began to work together to understand their experiences. By doing so, culture and cultural differences started to become apparent and the interactive conversations fostered intercultural understanding (Jund, 2010).

\section{Academic Success}

With regard to academic success, growing intercultural communicative competence appeared to be associated with higher levels of student satisfaction in EAP-type settings. In the pilot project developed by Campbell et al. (2014), teacher and student feedback indicated that a direct focus on intercultural skills was beneficial. Students in Galante's (2014) digital literacy project also reported satisfaction in connection to the relevance of exploring intercultural issues and their own identities as international students and newcomers to Canada. 
Along with higher levels of student satisfaction, it also appeared that increasing levels of intercultural communicative competence could lead to greater academic achievement. Higher grades were reported as going hand in hand with effective intercultural communicative competence (Martin, 2016). In a Canadian EAP setting, Martin (2016) found a relationship between levels of intercultural communicative competence and EAP student success in language learning. Martin measured students' levels of intercultural communicative competence using Hammer, Bennett, and Wiseman's (2003) Intercultural Development Inventory (IDI) and found that the EAP students with higher grades typically had higher levels of intercultural communicative competence. They also seemed to be more effective at interacting with their fellow students and teachers and overcoming the challenges of intercultural communication that might hinder students with lower levels of intercultural communicative competence. Martin developed a profile of a student with higher levels of intercultural communicative competence who was also academically successful. For Martin, students earning higher grades, completing their tasks and assignments, and following feedback typically were better able to demonstrate their knowledge and skills under pressure; had stronger critical thinking skills; found it easier to engage with teachers and classmates from diverse cultural backgrounds; exhibited more openness, curiosity, and willingness to communicate; understood the relationship between people's attitudes and behaviours with cultural difference; and could gain new knowledge related to culture. These skills seemed to combine to foster successful learning in EAP settings and pointed the way to a strong foundation for future academic success. Based on these findings, Martin concluded that intercultural communicative competence could actually benefit not just EAP students, but all students in higher education settings. Understanding culture and its relationship with behaviour and thinking patterns, critical thinking skills, and an openness to take part in intercultural interactions are positive traits for any student seeking academic success (Martin, 2016).

\section{Discussion}

After an extensive search, with only four peer reviewed articles directly focused on intercultural communicative competence and EAP, and a total of 15 scholarly works related to these two concepts, there appears to be scant literature on intercultural communicative competence in EAP settings. Although intercultural competence (Bennett, 1993; Deardorff, 2006) and intercultural communicative competence (Byram, 1997) have been well defined and explored, the topic does not seem to have been taken up by EAP researchers in a substantive way. However, EAP classrooms, with their students from a wide variety of culturally and linguistically diverse backgrounds, are prime locations for fostering intercultural understanding and communicative competence.

Fostering intercultural communicative competence in the EAP classroom could mitigate misconceptions (e.g., Clennnell, 1999) students and teachers may have when engaged in communication in an additional language. For students, these misconceptions could hinder language acquisition and academic progress, particularly when those misconceptions lead to a breakdown in communication and an increase in negative affective factors such as anxiety, frustration, and disengagement. Ethnocentric outlooks may also impede intercultural interactions and increase misunderstandings, such as in the Ellwood and Nakane (2009) study. Essentialist conceptions of culture are not conducive to fostering intercultural communicative competence. Thus, for improved classroom 
relationships and academic environments, a move away from ethnocentric perceptions and acculturation goals toward ethnorelative perceptions and a bidirectional flow of intercultural awareness and adaptation can foster intercultural communicative competence for members of EAP classroom communities and the wider academic settings of postsecondary studies.

During the analysis of the literature related to intercultural communicative competence and EAP, the themes of miscommunication, ethnocentrism, acculturation, awareness, ethnorelativism, identity, teaching and learning, and academic success emerged. These findings have a number of implications for the EAP classroom. First of all, they point to the importance of having educational approaches infused with an understanding of culture that fosters intercultural awareness and moves toward ethnorelative perspectives for both teachers and students. In particular, student-led inquiry projects that bring learners from culturally and linguistically diverse backgrounds together, such as in Galante's (2014) digital literacy project, hold great potential for EAP classrooms. The review of the literature also points to the need for specific and continuing professional development related to the teaching and learning of intercultural communicative competence in EAP settings. This type of professional development holds potential for mitigating ethnocentric perceptions, such as those uncovered during the review, and moving EAP programs of study away from acculturation and toward bidirectional intercultural competence. Finally, at the policy level for EAP programs, support for intercultural understanding has to come from administration and the institutions in which they are housed. Specific policies could be put into place in EAP programs that support the development of intercultural communicative competence. Furthermore, administrators can strive to understand the intercultural dynamics of the classroom communities within the wider context of the institutions they lead in order to minimize miscommunication and move away from ethnocentrism. By modelling intercultural communicative competence and interacting with students and faculty from an ethnorelative standpoint, administrators can further support policies that promote diversity and embrace intercultural understanding between students, faculty, and staff.

Much research is yet to be done in connection to intercultural communicative competence and EAP classrooms. One place to start could be exploring the beliefs and practices of current EAP teachers, similar to a study exploring these themes for general English as an additional language teachers (Bickley et al., 2014). A study such as this could also be expanded to consider the intercultural beliefs and practices of EAP administration and support staff. Work also needs to be done to explore the professional development needs of EAP teachers to identify how best to support them as they begin to promote intercultural communicative competence as part of the EAP curriculum. Teacher education is another area for future research to explore preservice EAP teachers' readiness for intercultural classrooms. Finally, an investigation of instructional strategies that integrate intercultural communicative competence into the EAP curriculum would also be an area for further study.

\section{Conclusion}

An extensive review of the literature uncovered 15 scholarly works related to intercultural communicative competence and EAP produced over a 20 -year period from 1996 to 2016. Given the rising importance of intercultural communicative competence in English language teaching, these results were surprisingly few, and indicated a need for 
further scholarly exploration of intercultural communicative competence in EAP settings. In analyzing and synthesizing the literature, eight major themes emerged from the data. Miscommunication among students and between students and teachers because of cultural misunderstandings was identified as an issue in EAP classrooms. In particular, teachers might misunderstand their students because of misconceptions related to ethnocentrism, and a point of view that sees student behaviour through a cultural lens of difference. Related to the theme of ethnocentrism, acculturation as a curricular goal was also found, with responsibility to adapting to the host culture resting with students from linguistically diverse backgrounds. However, ethnocentric practices could give way to ethnorelative perspectives, with other studies having noted how certain classroom practices, particularly those related to technology such as electronic bulletin boards (Spiliotopoulous \& Carey, 2005), email (Ruhe, 1998), and digital literacy projects (Galante, 2014), could foster student self-awareness and intercultural awareness to engender a new respect and understanding for other cultures. This theme of ethnorelativity was accompanied by the theme of identity, in which the complexity of the cultural self was acknowledged along with other factors that impact identity, such as gender, sexuality, and power relations. Educational practices that foster intercultural communicative competence were also presented in the literature, with intercultural group work and student-led projects pointing to instructional strategies that foster interculturality in EAP settings. Finally, the literature review revealed a relationship between intercultural communicative competence and EAP studies, with students having higher levels of intercultural communicative competence also having higher levels of academic success.

Correspondence should be addressed to Scott Douglas.

Email: scott.douglas@ubc.ca

\section{Acknowledgements}

The authors would like to extend their appreciation to the anonymous reviewers who contributed valuable feedback on an earlier draft of this article.

\section{References}

Atkinson, D. (1999). TESOL and culture. TESOL Quarterly, 33(4), 625-654.

Basturkmen, H. (2000). Discourse in discussions: A report of markers of detachment and commitment in discussion in university classes (ED438720). Retrieved from Auckland University, ERIC database.

Bennett, M. J. (1993). Towards a developmental model of intercultural sensitivity. In R. M. Paige (Ed.), Education for the intercultural experience (pp. 21-72). Yarmouth, ME: Intercultural Press.

Bennett, M. J. (1998). Intercultural communication: A current perspective. In M. J. Bennett (Ed.), Basic concepts of intercultural communication: Selected readings (pp. 1-34). Yarmouth, ME: Intercultural Press.

Bickley, C., Rossiter, M. J., \& Abbott, M. L. (2014). Intercultural communicative competence: Beliefs and practices of adult English as a second language instructors. Alberta Journal of Educational Research, 60(1), 135-160. 
Byram, M. (1997). Teaching and assessing intercultural communicative competence. Clevedon, United Kingdom: Multilingual Matters.

Campbell, C., MacPherson, S., \& Sawkins, T. (2014). Preparing students for education, work, and community: Activity theory in task-based curriculum design. TESL Canada Journal, 31(8), 68-92.

Canale, M. (1983). From communicative competence to communicative language pedagogy. In J. Richards \& R. Schmidt (Eds.), Language and communication (pp. 2-27). London, United Kingdom: Longman.

Canale, M., \& Swain, M. (1980). Theoretical bases of communicative approaches to second language teaching and testing. Applied Linguistics, 1(1), 1-47.

Celce-Murcia, M. (2007). Rethinking the role of communicative competence in language teaching. In E. A. Soler \& M. P. S. Jorda (Eds.), Intercultural language use and language learning (pp. 41-57). Dordrecht, Netherlands: Springer.

Celce-Murcia, M., Dörnyei, Z., \& Thurrell, S. (1995) A pedagogical framework for communicative competence: A pedagogically motivated model with content specifications. Issues in Applied Linguistics 6(2), 5-35.

Cheng, L., \& Fox, J. (2008). Towards a better understanding of academic acculturation: Second language students in Canadian universities. The Canadian Modern Language Review 65(2), 307-333.

Citizenship and Immigration Canada. (2013). Facts and figures 2012 - Immigration overview: Permanent and temporary residents: Permanent residents (Ci1-8/2012EPDF). Retrieved from http://publications.gc.ca/collections/collection_2013/cic/Ci18-2012-eng.pdf

Clennell, C. (1999). Promoting pragmatic awareness and spoken discourse skills with EAP classes. ELT Journal, 53(2), 83-91.

Creswell, J. (1998). Qualitative inquiry and research design: Choosing among five traditions. Thousand Oaks, CA: Sage Publications.

Deardorff, D. K. (2006). Identification and assessment of intercultural competence as a student outcome of internationalization. Journal of Studies in International Education, 10(3), 241-266.

Deardorff, D. K. (2010). Theory reflections: Intercultural competence framework/model. Retrieved from NAFSA, Association of International Educators: http://www.nafsa.org/_File/_theory_connections_intercultural_competence.pdf

Deardorff, D. K. (2011). Assessing intercultural competence. New Directions for Institutional Research, 2011(149), 65-79.

Ellwood, C., \& Nakane, I. (2009). Privileging of speech in EAP and mainstream university classrooms: A critical evaluation of participation. TESOL Quarterly, 43(2), 203230.

Flowerdew, J., \& Peacock, M. (2001). Issues in EAP: A preliminary perspective. In J. Flowerdew \& M. Peacock (Eds.), Research perspectives on English for academic purposes (pp. 8-24). Cambridge, United Kingdom: Cambridge University Press.

Foreign Affairs, Trade and Development Canada. (2014). Canada's international education strategy: Harnessing our knowledge advantages to drive innovation and prosperity (Cat. No.: FR5-86/2014). Retrieved from http://international.gc.ca/global-marketsmarches-mondiaux/assets/pdfs/overview-apercu-eng.pdf

Galante, A. (2014). Developing EAL learners' intercultural sensitivity through a digital literacy project. TESL Canada Journal, 32(1), 53-66. 
Garcia-Perez, G., Ragoonaden, K., \& Campbell, R. (2014). English language learners and intercultural competence. Journal of New Horizons in Education, 4(1) 39-48.

Gay, L. R., Mills, G. E., \& Airasian, P. (2012). Educational research: Competencies for analysis and applications $\left(10^{\text {th }}\right.$ ed.). Boston, MA: Pearson Education.

Grayson, P. (2008). The experiences and outcomes of domestic and international students at four Canadian universities. Higher Education Research and Development, 27(3), 215-230.

Hall, E. T. (1976). Beyond culture. New York, NY: Random House.

Hammer, M. R., Bennett, M. J., \& Wiseman, R. (2003). Measuring intercultural sensitivity: The intercultural development inventory. International Journal of Intercultural Relations, 27(4), 421-443.

Hyland, K. (2006). English for academic purposes: An advanced resource book. Abingdon, United Kingdom: Routledge.

Hyland, K., \& Hamp-Lyons, L. (2002). EAP: Issues and directions. Journal of English for Academic Purposes, 1(1), 1-12.

Hymes, D. H. (1966). Two types of linguistic relativity. In W. Bright (Ed.), Sociolinguistics (pp. 114-158). The Hague, Netherlands: Mouton.

Hymes, D. H. (1972). On communicative competence. In J. B. Pride \& J. Holmes (Eds.), Sociolinguistics: Selected readings (pp. 269-293). Harmondsworth, United Kingdom: Penguin.

Jund, A. (2010). Toward a pedagogy of intercultural understanding in teaching English for academic purposes. The Electronic Journal for English as a Second Language, 14(1), 1-13.

Kennedy, C. (2001). Language use, language planning, and EAP. In J. Flowerdew \& M. Peacock (Eds.), Research perspectives on English for academic purposes (pp. 8-24). Cambridge, United Kingdom: Cambridge University Press.

Krahn, H., \& Taylor, A. (2005). Resilient teenagers: Explaining the high educational aspirations of visible minority youth in Canada. Journal of International Migration and Integration, 6(3), 405-434.

Krasnick, H. (1985). Intercultural competence in ESL for adults. JALT Journal, 7(1), 1541.

Liu, L. (2007). Acquiring English for academic purposes: Challenges ESL students experience in an English-speaking Canadian university (Unpublished master's thesis). University of Regina, Regina, SK.

Martin, D. L. (2016). Exploring the relationship between intercultural competence and academic success among English for academic purposes students (Unpublished master's thesis). University of Toronto, Toronto, ON.

Ruhe, V. (1998). E-mail exchanges: Teaching language, culture, and technology for the $21^{\text {st }}$ century. TESL Canada Journal, 16(1), 88-95.

Sauvé, V. (1996). Working with the cultures of Canada in the ESL classroom: A response to Robert Courchêne. TESL Canada Journal, 13(2), 17-23.

Singh, P., \& Doherty, C. (2004). Global cultural flows and pedagogic dilemmas: Teaching in the global university contact zone. TESOL Quarterly, 38(1), 9-42.

Spack, R. (1997). The rhetorical construction of multilingual students. TESOL Quarterly, 31(4), 765-774.

Spiliotopoulos, V., \& Carey, S. (2005). Investigating the role of identity in writing using electronic bulletin boards. Canadian Modern Language Review, 62(1), 87-109. 
Statistics Canada. (2012). 2011 Census of population: Linguistic characteristics of Canadians (Publication No. 11-001-X). Retrieved from http://www.statcan.gc.ca/daily-quotidien/121024/dq121024a-eng.pdf

Stoller, F. (1999). Time for change: A hybrid curriculum for EAP programs. TESOL Journal, 8(1), 9-13.

Sun, Y. (2014, December 15). What is intercultural communicative competence? [Blog post]. Retrieved from http://blog.tesol.org/what-is-intercultural-communicativecompetence/

Thatcher, B. (2004). Rhetorics and communication media across cultures. Journal of English for Academic Purposes, 3(4), 305-320.

University of British Columbia. (2011). UBC international strategic plan. Retrieved from https://research.ubc.ca/sites/research.ubc.ca/files/vpri/UBC-intl-strat-plan-2011.pdf 